\title{
Challenges on Marine Environment Pollution under Marpol Convention
}

Alim A*

Department of Law, University of Rajshahi, Bangladesh

*Corresponding author: Abdul Alim, Professor Department of Law, University of Rajshahi, 6205, Bangladesh, Tel: 88-01714896132; Email: alimlaw05@gmail.com
Research Article

Volume 4 Issue 2

Received Date: March 17, 2021

Published Date: April 01, 2021

DOI: $10.23880 /$ abca-16000174

\section{Abstract}

Natural disasters may take place even more frequently and be greater in magnitude. A rise in sea levels could submerge a considerable proportion of the country. The legal regulations per specific aspects of maritime law are the priority of lawyers as natural risks like rising sea levels, storm surges, or tsunami waves, the pollution of the marine environment represents a severe threat to coastal inhabitants. Global climate change will thus not only cause environmental demolition, but will drive massive social changes as innumerable people migrate from devastated areas. Thus, the proposed article would contribute to the expansion of the current regime of the bay water used for cooling purposes of atomic energy plant preventing its use for fish farming purposes, an oil spill on the high seas polluting beaches that are essential for tourism within the coastal zone and the way of such activities destroys on our natural climate and it changes water level, ocean acidification, ocean stratification, coral bleaching, changing species distributions and other biological change to sea.

Keywords: Climate Change; Marine Environment; Ecological Aspect; Marpol Convention; Challenges

\section{Introduction}

\section{Marine Pollution}

Pollution is often categorized as point source or nonpoint source pollution. Point source pollution take places when there is a single, identifiable, localized source of the pollution. An example is directly discharging sewage and industrial waste into the ocean. Pollution such as this occurs particularly in developing nations. Nonpoint source pollution occurs when the pollution comes from ill-defined and diffuse sources. These can be difficult to standardize. Agricultural run-off and windblown debris are prime examples. Under climate change projection scenarios low rainfall in the waterless season will be further diminished. As a result winter and pre-monsoon temperature will increase significantly and thus drought intensity will be further amplified. It will cause a sharp decline in river flow. Salinity will break through inland that will ultimately restrict choice for the most preferred crops. High and moderate level water demanding plants and organisms will go extinct locally.

Polluting materials penetrate the marine ecosystem via a number of pathways, in particular:

- Riverine runoff mainly land based pollution from sewage, garbage, fertilizers, pesticides and industrial pollution

- Atmospheric deposition basically pollute ion from ships by oil, noxious liquid substances in bulk, harmful substances carried in packaged form, sewage, garbage, air pollution, greenhouse gas emissions from ships and harmful aquatic organisms carried by ballast water and introduced by bio-fouling.

- Direct discharges from land and that is offshore hydrocarbon exploration and mining (prospecting, 
drilling, and transport);

- Activities at sea such as unsustainable use and overexploitation of marine resources.

\section{Pollution from Ships}

Ships can contaminate waterways and oceans in numerous ways. Oil spills can have devastating effects. While being contaminated to marine life, polycyclic aromatic hydrocarbons (PAHs), found in crude oil, are very difficult to clean up, and last for years in the sediment and marine environment. Oil spillages from ships as a result of illegal discharges of oil residues or caused by an accident are another matter of apprehension. The same is true for oil spills originating from offshore activities. However, it is significant to note that land based sources are by far the largest contributor to oil inputs.

\section{Plastic Debris}

Plastic bottles and other plastic products are most common forms of debris in the coastal water. Marine debris is mainly discarded human garbage which floats on, or is suspended in the ocean. Eighty percent of marine fragments is plastic a module that has been rapidly accumulating since the end of World War II. In the ocean present threats are formed of plastic materials which conclude the life to wildlife and fisheries. Floating plastic particles photo degrade down to zooplankton sizes, jellyfish attempt to consume them, and in this way the plastic enters into the ocean food chain. Aquatic life can be threatened through entanglement, suffocation, and ingestion. Fishing nets, frequently made of plastic, can be left or lost in the ocean by fishermen. Known as ghost nets, these entangle fish, dolphins, sea turtles, sharks, dugongs, crocodiles, seabirds, crabs, and other living things, restricting movement, causing starvation, laceration, infection, and, in those that need to return to the surface to breathe, suffocation [1].

\section{Marpol Convention}

Marpol Convention is subject to achieve complete elimination of international pollution by oil and other harmful substance and minimize of accidental discharge of such substances [2,3]. Its requirements, regardless of their navigation and member nations are accountable for vessels registered on their national ship registry. MARPOL is divided into Annexes according to various categories of pollutants, each of which compacts with the regulation of a particular group of ship emissions.

\begin{tabular}{|c|c|c|c|}
\hline \multicolumn{4}{|c|}{ List of the MARPOL 73/78 Annexes } \\
\hline Annex & Title & Entry into Force & Objectives \\
\hline Annex I & $\begin{array}{l}\text { Prevention of } \\
\text { pollution by oil \& oily } \\
\text { water }\end{array}$ & 2-Oct-1983 & $\begin{array}{c}\text { It specifies tanker design features that are intended to minimize } \\
\text { oil discharge into the ocean during ship operations and in case of } \\
\text { accidents. It provides regulations with regard to treatment of engine } \\
\text { room bilge water (OWS) for all large commercial vessels and ballast } \\
\text { and tank cleaning waste }\end{array}$ \\
\hline Annex II & $\begin{array}{l}\text { Control of pollution } \\
\text { by noxious liquid } \\
\text { substances in bulk }\end{array}$ & 6-Apr-1987 & $\begin{array}{l}\text { It divides substances into and introduces detailed operational } \\
\text { standards and measures. The discharge of pollutants is allowed only } \\
\text { to reception facilities with certain concentrations and conditions. } \\
\text { No matter what, no discharge of residues containing pollutants is } \\
\text { permitted within } 12 \text { miles of the nearest land. }\end{array}$ \\
\hline $\begin{array}{l}\text { Annex } \\
\text { III }\end{array}$ & $\begin{array}{l}\text { Prevention of } \\
\text { pollution by harmful } \\
\text { substances carried by } \\
\text { sea in packaged form }\end{array}$ & 1-Jul-1992 & $\begin{array}{l}\text { It contains general requirements for the standards on packing, } \\
\text { marking, labeling, documentation, stowage, quantity subtraction, } \\
\text { division and notifications for preventing pollution by harmful } \\
\text { substances. }\end{array}$ \\
\hline $\begin{array}{c}\text { Annex } \\
\text { IV }\end{array}$ & $\begin{array}{l}\text { Pollution by sewage } \\
\text { from ships }\end{array}$ & 27-Sep-2003 & $\begin{array}{l}\text { It introduces requirements to control pollution of the sea by sewage } \\
\text { from ships. }\end{array}$ \\
\hline $\begin{array}{l}\text { Annex } \\
V[4]\end{array}$ & $\begin{array}{l}\text { Pollution by garbage } \\
\text { from ships }\end{array}$ & 31-Dec-1988 & $\begin{array}{l}\text { It specifies the distances from land in which materials may be } \\
\text { disposed of and subdivides different types of garbage and marine } \\
\text { debris. The requirements are much stricter in a number of "special } \\
\text { areas" but also the most prominent part of the Annex is the complete } \\
\text { ban of dumping plastic into the ocean. }\end{array}$ \\
\hline $\begin{array}{l}\text { Annex } \\
\text { VI [5] }\end{array}$ & $\begin{array}{l}\text { Prevention of air } \\
\text { pollution from ships }\end{array}$ & 19-May-2005 & $\begin{array}{l}\text { It introduces requirements to regulate the air pollution being } \\
\text { emitted by ships, including the emission of ozone-depleting } \\
\text { substances, Nitrogen Oxides (NOx), Sulphur Oxides (SOx), Volatile } \\
\text { Organic Compounds (VOCs) and shipboard incineration. }\end{array}$ \\
\hline
\end{tabular}


All six Annexes have been ratified by the requisite number of nations; and Annex VI, which took effect in May 2005 and has been amended and lastly came into force on 1 July 2010. The country where a ship is registered named as Flag State is responsible for certifying the ship's compliance with MARPOL's pollution prevention standards. Flag State is accountable for enacting domestic laws to execute the convention and promises to comply with the convention, annexes, and related laws of other nations [6]. One of the difficulties in implementing MARPOL arises from the international nature of maritime shipping. When they find noncompliance with international standards and in according with MARPOL the country refers cases to flag states. It was seen by UN report documented that the response rate from flag states has been very poor [7].

According to MARPOL directives the SECA (Sulphur Emission Controlled Areas) zone is increased day by day and includes the North Sea, Scandinavia, and parts of the English Channel. All of Western Europe's weakness is to the MARPOL directive which proven controversial for shipping and ferry operators across Europe. It is a great concern on environmental damage with larger ferry operators that ship substantial amounts of freight and passenger traffic via these routes affected by IMO standards [8].

\section{Conclusion}

Marine pollution was an apprehension during several United Nations Conventions on the Law of the Sea beginning in the 1950s. In the late 1950s and early 1960s, there have been several controversies about dumping radioactive materials off the coasts of the United States by companies licensed by the Atomic Energy Commission, into the Irish Sea from the British reprocessing facility at Wind scale. Marine pollution made further international headlines after the 1967 crash of the oil tanker Torrey Canyon, and after the 1969 Santa Barbara oil spill off the coast of California.

Marine pollution was a major area of discussion during the 1972 United Nations Conference on the Human Environment, held in Stockholm. In this year London Convention was taken by the signing of the Convention on the Prevention of Marine Pollution by Dumping of Wastes and Other Matter. The London Convention did not ban marine pollution, but it established black and gray lists for substances to be banned (black) or regulated by national authorities (gray).

\section{References}

1. (2007) "Ghost fishing' killing seabirds". BBC News.

2. (1973) The International Convention for the Prevention of Pollution from Ships, as modified by the Protocol of 1978 (MARPOL 73/78, MARPOL is short for marine pollution and 73/78 short for the years 1973 and 1978) is one of the most important international marine environmental conventions. It was developed by the International Maritime Organization in an effort to minimize pollution of the oceans and seas, including dumping, oil and air pollution.

3. Preamble of the 1973 Convention.

4. (2012) MARPOL Annex V has been amended multiple times, changing different aspects of the original text. At last, it came into force to generally prohibit the discharge of any garbage into the ocean, with the exception of food wastes, cargo residues, wash-water, and animal carcasses. There are further provisions describing when and how to dispose of the acceptable wastes.

5. MARPOL Annex VI amendments according with MEPC 176(58) came into force 1 July 2010. Amended Regulations 12 concerns control and record keeping of Ozone Depleting Substances. Amended Regulation 14 concerns mandatory fuel oil change over procedures for vessels entering or leaving SECA (Sulphur Emission Controlled Areas) areas and FO sulphur limits.

6. (2013) Copeland, Claudia "Cruise Ship Pollution: Background, Laws and Regulations, and Key Issues" Archived at the Wayback Machine. (Order Code RL32450). Congressional Research Service. This article incorporates text from this source, which is in the public domain.

7. (2000) "Marine Pollution: Progress Made to Reduce Marine Pollution by Cruise Ships, but Important Issues Remain". U.S Government Accountability.

8. Tanaka Y (2012) The International Law of the Sea. Cambridge: Cambridge University Press, pp: 279-281. 